\title{
PURSUING THE TRAIL OF PESTICIDES AND MERCURY IN AQUATIC BIRDS REMINISCENCES OF A BIOLOGIST
}

\section{Kees Vermeer}

8968 Mainwaring Road

North Saanich, BC V8L 1J7

keesvermeer@telus.net

In 1968, I was transferred from the Canadian Wildlife Service (CWS) Migratory Birds Section to the Pesticide Section because of my work on fish-eating birds, which were suspected to contain high DDE residue levels. Although the CWS Pesticide Section was small, it strongly influenced how CWS evolved. I contributed by producing publications on organochlorine and mercury residues found in aquatic birds throughout the Prairie Provinces. These publications reveal which species and where birds were most at risk from pollutants. One investigation, entitled "Spotted Sandpipers as possible indicators of mercury contamination in rivers" published in Blue Jay, ${ }^{1}$ combined with the discovery of my neighbour having a freezer full of mercury contaminated fish caught in the North Saskatchewan River downstream of Edmonton, led to the discovery that industry and the University in Edmonton were sources of mercury pollution and eventually to a reduction of mercury entering the river. The revelation of those sources made news in the Edmonton Journal to the chagrin of the CWS director at that time, who accused me of exposing "good corporate citizens of Edmonton".

As little was known about the extent of pesticide residues present in aquatic birds in Alberta, Saskatchewan and Manitoba, I began

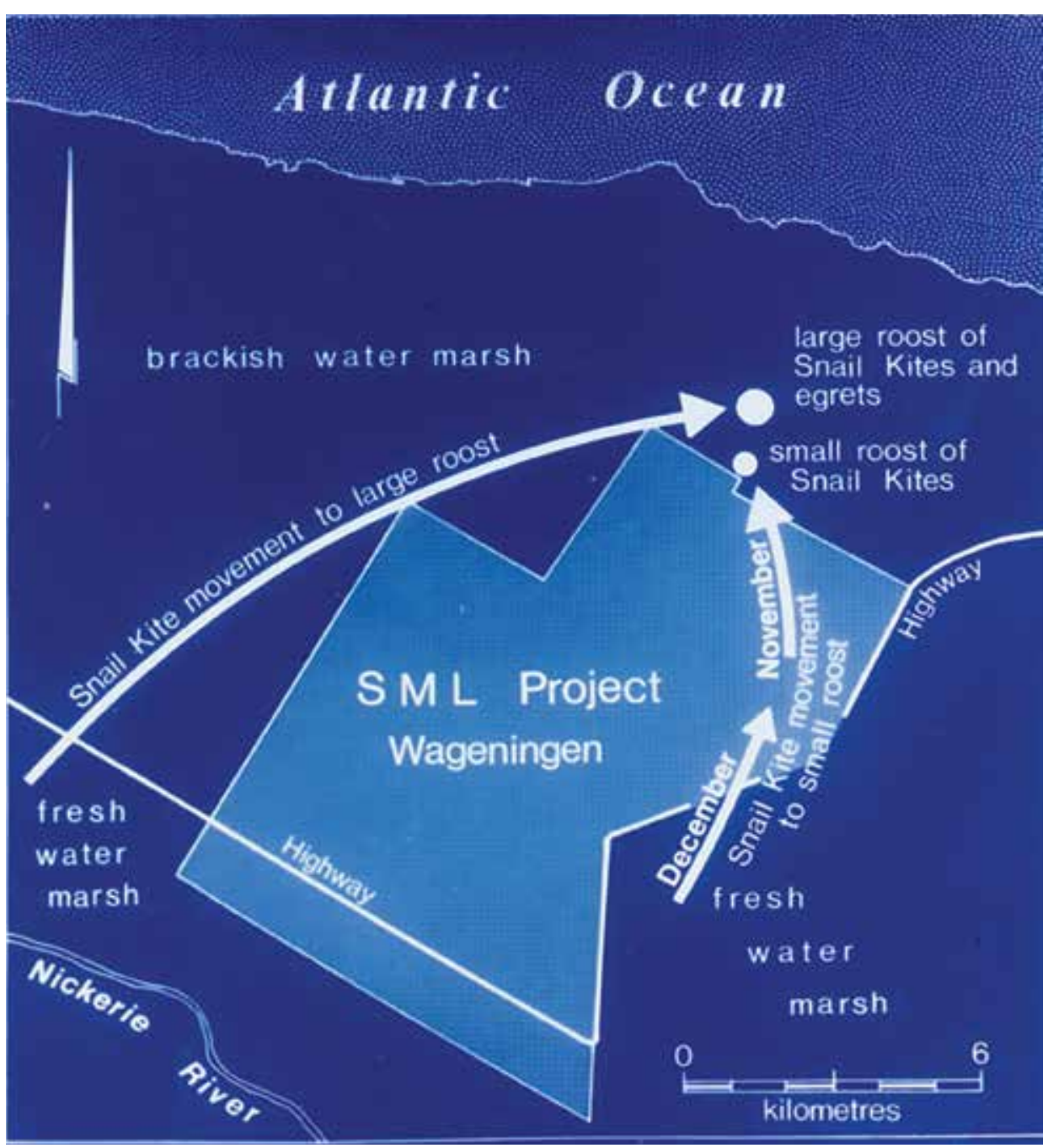

FIGURE 1. SML Project in Suriname, South America

a massive sampling program of eggs from 16 aquatic bird species at 31 locations in those provinces. ${ }^{2}$ Eggs were chosen to be analyzed as they are easy to collect and constitute distinct units of comparison. One significant result of that program was that high DDE levels were discovered in Great Blue Heron (Ardea Herodias) eggs from Alberta. 2,3 Shell thickness was found to be significantly and inversely correlated with the concentration of DDE in those eggs. Besides fish-eating birds, reduced shell thickness has been found to be correlated with the amount of DDE in the egg contents of raptors. ${ }^{4,5}$ Experimental studies with Mallards had shown that DDE can reduce thickness and cracking of eggshells. ${ }^{6}$

When a visiting Scandinavian student found elevated mercury residues in some Canadian birds, I immediately had the same set of bird egg samples analyzed for mercury residues. I presented the information on mercury residue levels in aquatic birds in the Canadian Prairie Provinces 


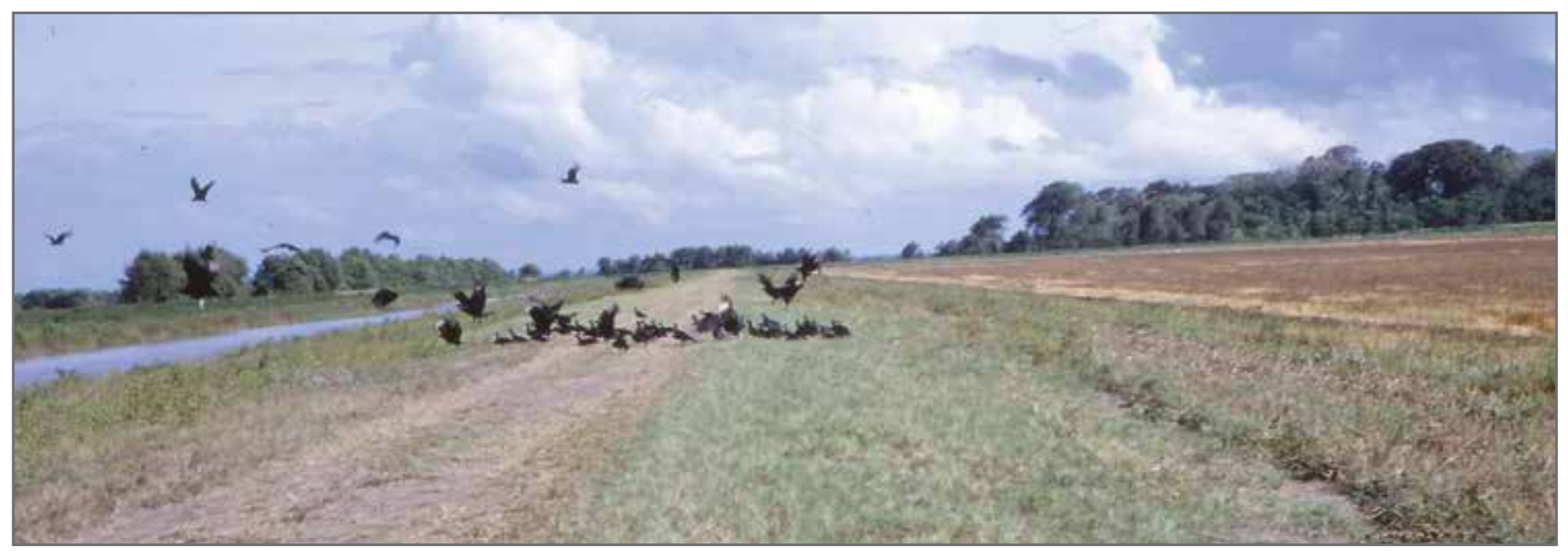

FIGURE 2. Black Vultures on access road through SML rice paddies.

to the North American Wildlife and Nature Resources Conference in 1971. ${ }^{7}$ Each seat in the auditorium was taken as mercury contamination was then a new and hot topic. At the end of the presentation, a lively discussion ensued. We discussed the differences in uptake of mercury by seed-eating and fish-eating birds. Seed-eating birds obtained alkyl mercury compounds from feeding on mercury-treated grain and seeds, while birds feeding on fish and aquatic invertebrates acquire inorganic mercury or phenyl mercury compounds in the form of slimicides released by chlor-alkali plants and pulp mills. Mercury levels in fisheating birds were observed to be much higher than those in seedeating birds. Several questions were from people who had just initiated an investigation of mercury residues in birds. For example, a biologist from Saskatchewan, who had begun an investigation of mercury in muscle tissues of Ring-necked Pheasants, Gray Partridge and Sharp-tailed Grouse in the southern part of that province wanted to know about the relationship between mercury levels in eggs and muscles of those birds. He found that the levels of mercury in muscle tissue only in one case exceeded 0.05 parts per million. A biologist from Alaska who had

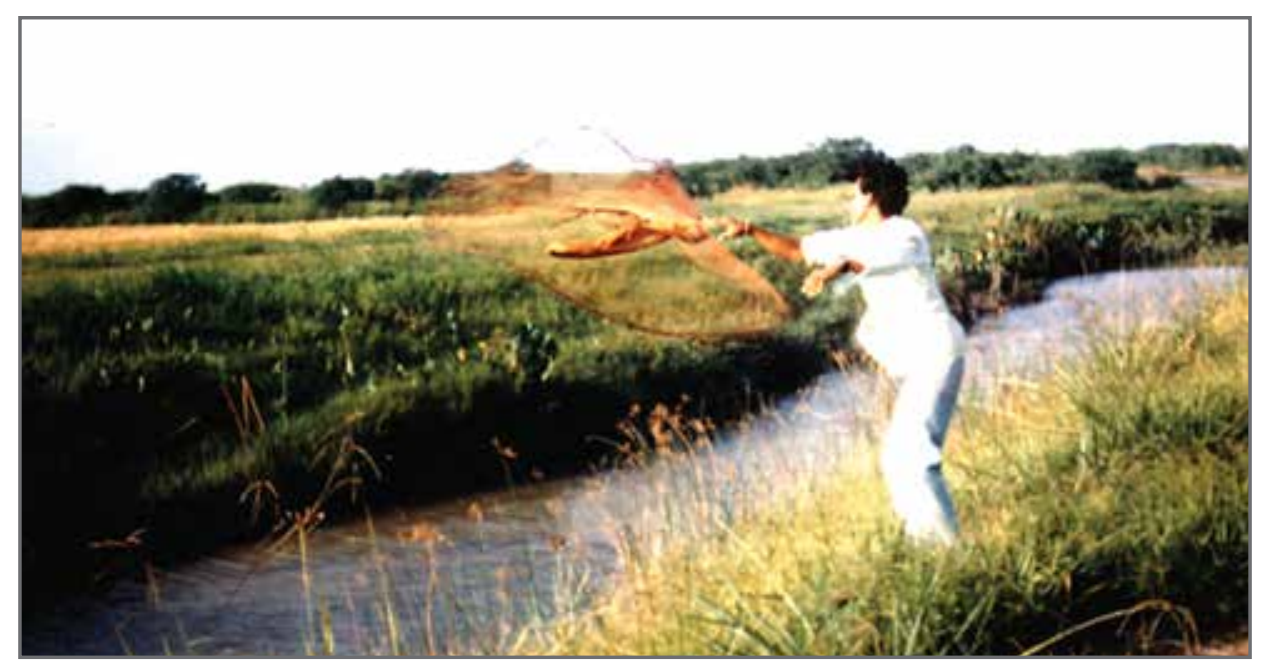

FIGURE 3. Local volunteer throws net to catch fishes in SML ditch. Fishes, which Common and Snowy Egrets feed upon, were analyzed for pesticide residues.

started a mercury analysis program on fish in that State, asked if I had done any analysis on fish tissues, and if so, how did mercury residues stack up in fish that these birds consumed. I had not conducted such analysis, but because of my involvement in a study with the Freshwater Institute in Winnipeg, I learned that levels in fish were generally higher than in eggs of fish-eating birds. Discussions on other topics are documented in my presentation at that Conference. ${ }^{7}$

Besides using large sampling programs of aquatic bird eggs, I examined bird tissues and aquatic invertebrates to determine whether they could serve as indicators of mercury contamination. One investigation, where I examined the relationship between mercury in breast muscles and wing muscles of ducks, had immediate consequences. Annually, CWS collected tens of thousands of duck wings from hunters across Canada in order to determine species, age and sex composition of harvested birds. Muscle tissues adhering to the wings were analyzed to monitor levels of mercury in ducks. From a public perspective, it was important to know the mercury content in the muscle tissues used for human consumption. If the ratio of mercury residues in wing muscle to those in breast muscle were known, and if it did not vary significantly, such information would be useful in predicting levels of mercury in breast muscle. 
Because fish in Clay Lake, which is part of the Wabigoon River system downstream of Dryden in western Ontario, were known to be among the most heavily contaminated by mercury in Canada, five species of ducks were collected from there prior to the hunting season. Highly significant correlations were found between levels of mercury in breast and wing muscles of Blue-winged Teals (Anas discors), Mallards (Anas platyrhynchos), Common Goldeneyes (Bucephala clangula) and Common Mergansers (Mergus merganser). ${ }^{8}$ In spite of the small sample size (seven birds) of Hooded Mergansers (Lophodytes cucullatus), there still was a significant correlation between mercury levels in breast and wing muscles. As a result of the high levels of mercury found in the ducks' breast muscles, the hunting season was closed for all ducks in that region.

Breast muscles of Hooded Mergansers at Clay Lake contained the highest levels of mercury. 89 Hooded Mergansers fed on crayfish which of all food items were most contaminated with mercury. ${ }^{9}$ Consequently I examined whether the crayfish Orconectes virilis, which feeds on detritus and scavenges on fish, could serve as indicator of mercury contamination. Orconectes virilis is also more restricted in its movements than fish and is the most widely distributed crayfish species in Canada. Crayfish were sampled at locations that were known to represent a range from low (Lake Winnipegosis) to very high (Clay Lake) mercury levels reported in fish. Mercury levels between crayfish from Clay Lake, the Saskatchewan River and Lake Winnipegosis varied significantly. ${ }^{10}$ By contrast, mercury levels in crayfish sampled at eight different sampling stations from Clay Lake varied little. ${ }^{10} \mathrm{I}$ concluded that Orconectes virilis is a good indicator of mercury in different water bodies provided the crayfish are within the same range of body weight. At low levels of contamination, crayfish muscle was a more reliable indicator of mercury than the whole animal. This was not surprising as crayfish muscle contained three times as much mercury as the rest of its body. Besides crayfish at Clay Lake, mayfly nymphs, water scorpions and water boatmen were also highly contaminated with mercury which may reflect their predatory feeding habits on small aquatic animals.

\section{Pesticide Effects on Birds in Rice Fields of Suriname, South America}

Because of my work with contaminants in aquatic birds in Canada, the Director of the Surinam Lands Bosbeheer invited me to investigate the effects of pesticides on birds in the rice polders of Wageningen in Suriname in 1971. My friend, Arie Spaans, a Dutch ornithologist, who lived at that time in Paramaribo, was the catalyst for that request. In early October, I travelled from Edmonton to Paramaribo, the capital of Suriname. At that time Paramaribo was an interesting white city with a Dutch colonial character. I initially stayed with Arie and his wife and had a great time admiring tropical flowers, birds and butterflies as it was my first time in the tropics. Small green frogs lived in homes and were considered part of the household. Large beetles and beautiful butterflies entered the house at night through open windows, drawn in by the light.

After acquiring a Volkswagen, I moved on to Wageningen along the coast in the western part of the country where I took up accommodation in hotel De Wereld for the next two months. From there I conducted my research on the effects of pesticides on Snail Kites (Rosthramus sociabilis), egrets and other birds on the 8,000-hectare rice growing project of the Stichting of Machinale Landbouw (SML, Figures 1,2 and 3).

Not unlike a detective, I loved piecing together the effects of sodium pentachlorophenate (NaPCP), the molluscicide sprayed by airplane to kill Pomacea snails feeding on rice plants in the polders (Figure 4). Thousands of fishes were also killed in the rice paddies during the application of NaPCP (Figure 5). Many dead Snail Kites were found on their roosts in the brackish water marsh north of the polders as a result of eating the NaPCP contaminated snails in the adjacent rice fields (Figures 1, 6 and 7). Snail Kite organs were removed for pesticide analyses

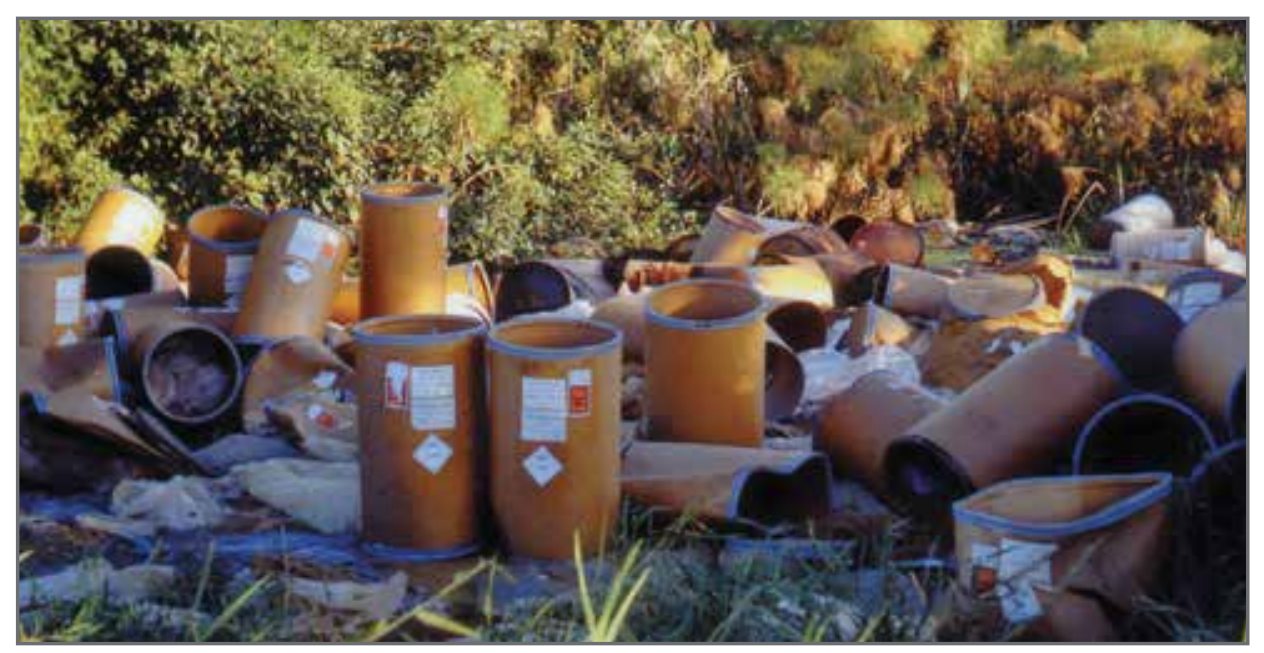

FIGURE 4. Disposal of NaPCP barrels. SML staff were advised to dispose the barrels safely as commercial preparations of NaPCP contain high levels of dioxin, a known teratogenic compound. 


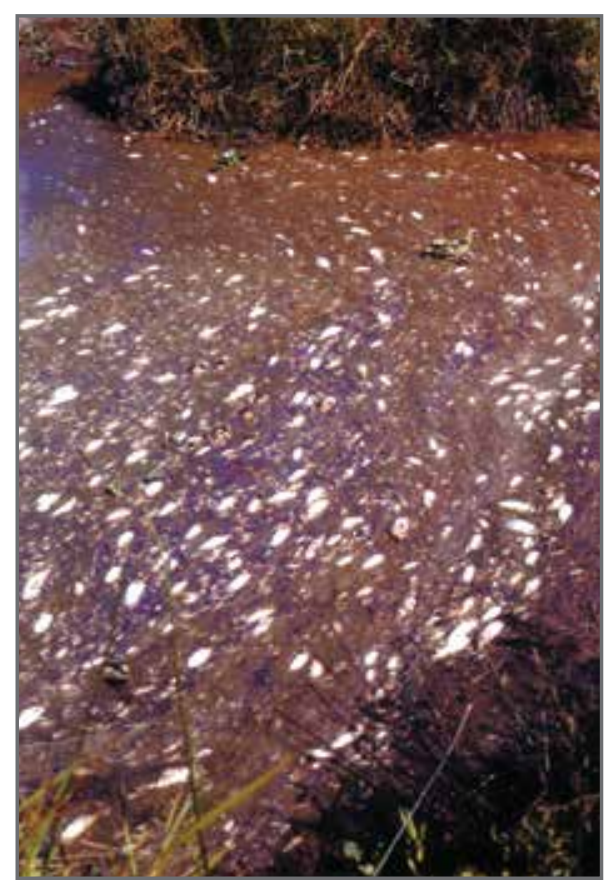

FIGURE 5. Fishes killed in rice paddy after aerial spraying of NaPCP. Chemical analyses showed high levels of pentachlorophenol in pooled samples of dead fishes.

and the cadavers thrown afterwards into a polder ditch where they were devoured within a few minutes by piranhas. Our study was one of the first well documented studies of the effects of NaPCP on birds of prey in an aquatic habitat. ${ }^{11}$ Because of the observed mass mortality of Snail Kites resulting from the application of NaPCP in the rice fields, we recommended that another less toxic pesticide with a shorter half life should be used to control Pomacea snails. That recommendation was followed up and Snail Kite mortality decreased dramatically. Besides $\mathrm{NaPCP}$, the effects of other pesticides (such as Endrin) on birds were investigated as well. At the end of the study, I presented in Dutch my preliminary findings to SML staff and other interested parties. A journalist from the main Paramaribo newspaper was present at the meeting. Shortly afterwards, the story was major news.

Several species of herons and egrets (8), caracaras, hawks, kites and vultures (10) and plovers, sandpipers

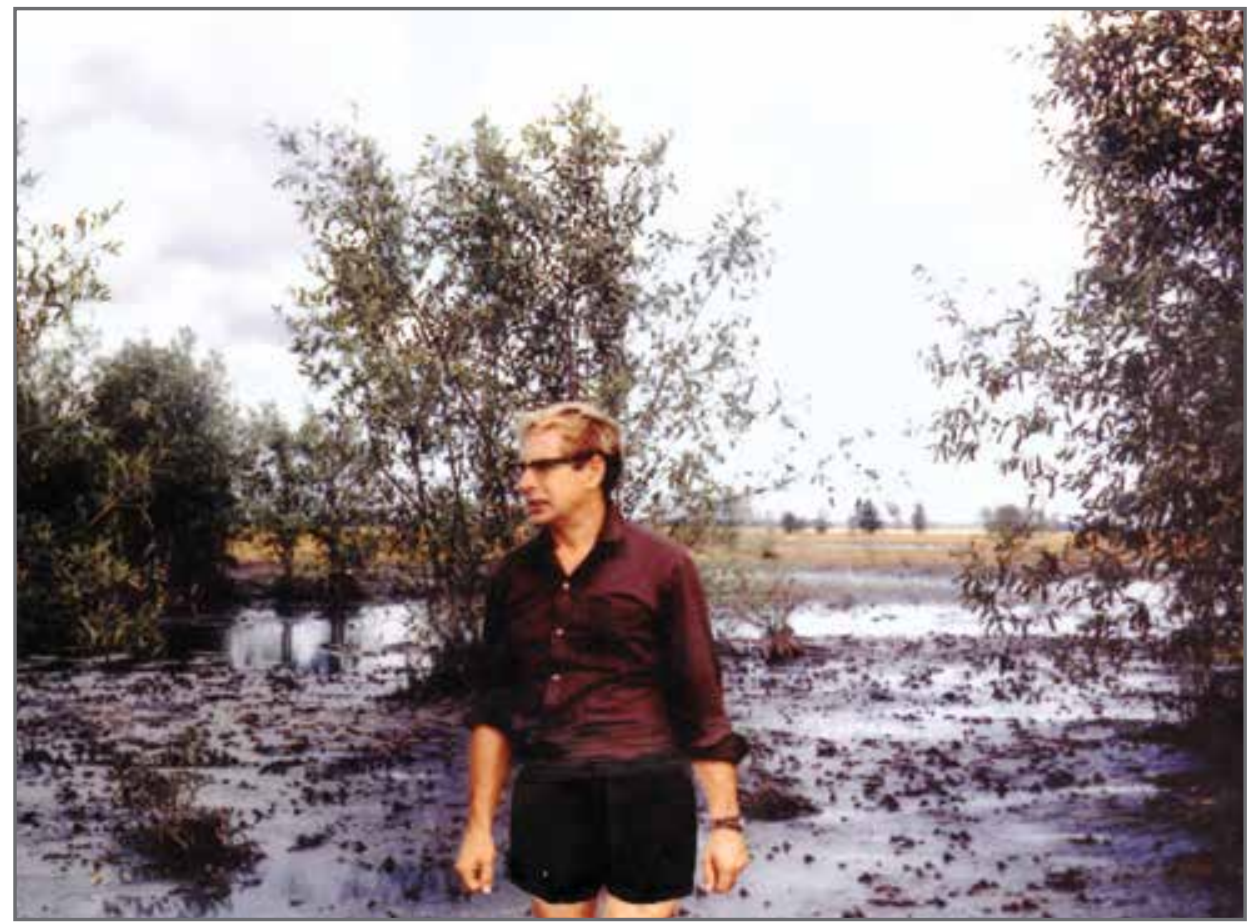

FIGURE 6. Kees Vermeer searching for dead birds (Snail Kites and egrets) in brackish water marsh adjacent to SML rice polder.

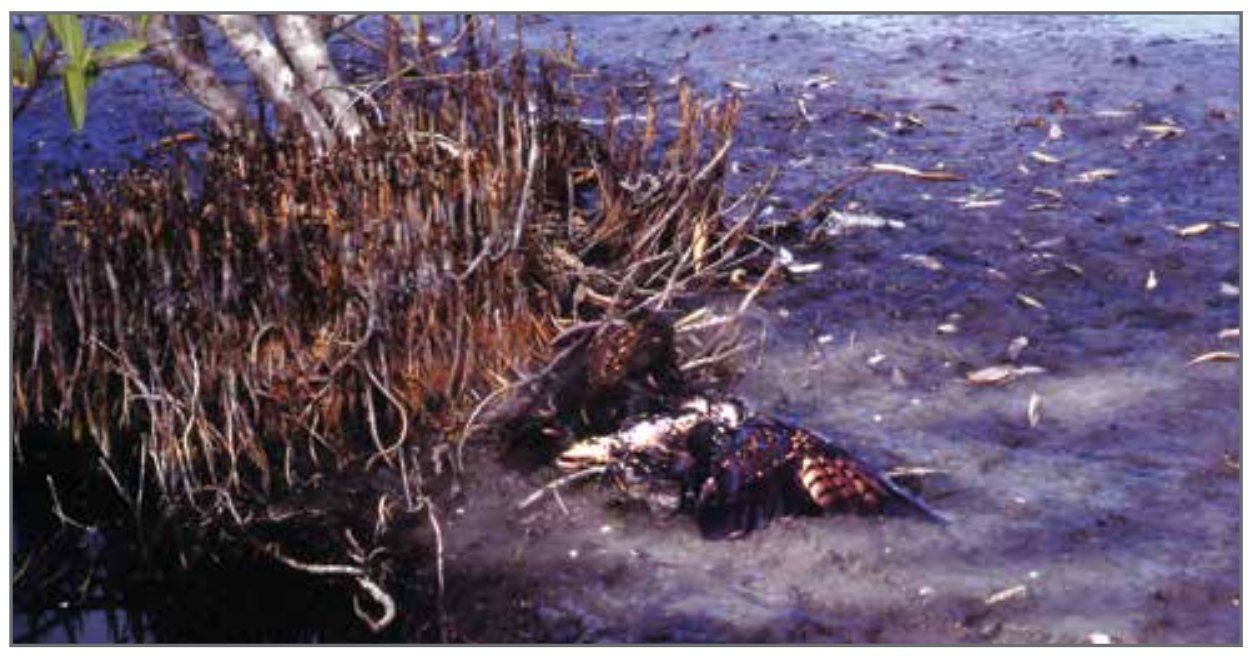

FIGURE 7. Dead Snail Kite beneath a black mangrove bush in brackish water marsh.

and yellowlegs (7), as well as other birds associated with aquatic habitats such as gallinules, limpkins, jacanas and terns were observed in the rice polders and adjacent brackish water marsh. ${ }^{11}$ All seven species of shorebirds that I observed were North American migrants, of which Upland Plovers, Spotted Sandpipers, Greater and Lesser Yellowlegs are widely distributed nesting birds in the Canadian Prairie Provinces. ${ }^{12}$ North America and coastal Suriname share tens of thousands and at least 16 species of shorebirds, of which the Semipalmated Sandpiper is the most numerous migrant from Alaska and Canada. ${ }^{13}$

Besides my field research, Arie and I made a boat trip along the Coppename River from Bitagron to the Voltzberg-Raleigh Falls Nature Reserve in the interior of Suriname. Along the river there were small settlements where women prepared manioc and beautiful coloured macaws flew from tree top to tree top. When we arrived at the 


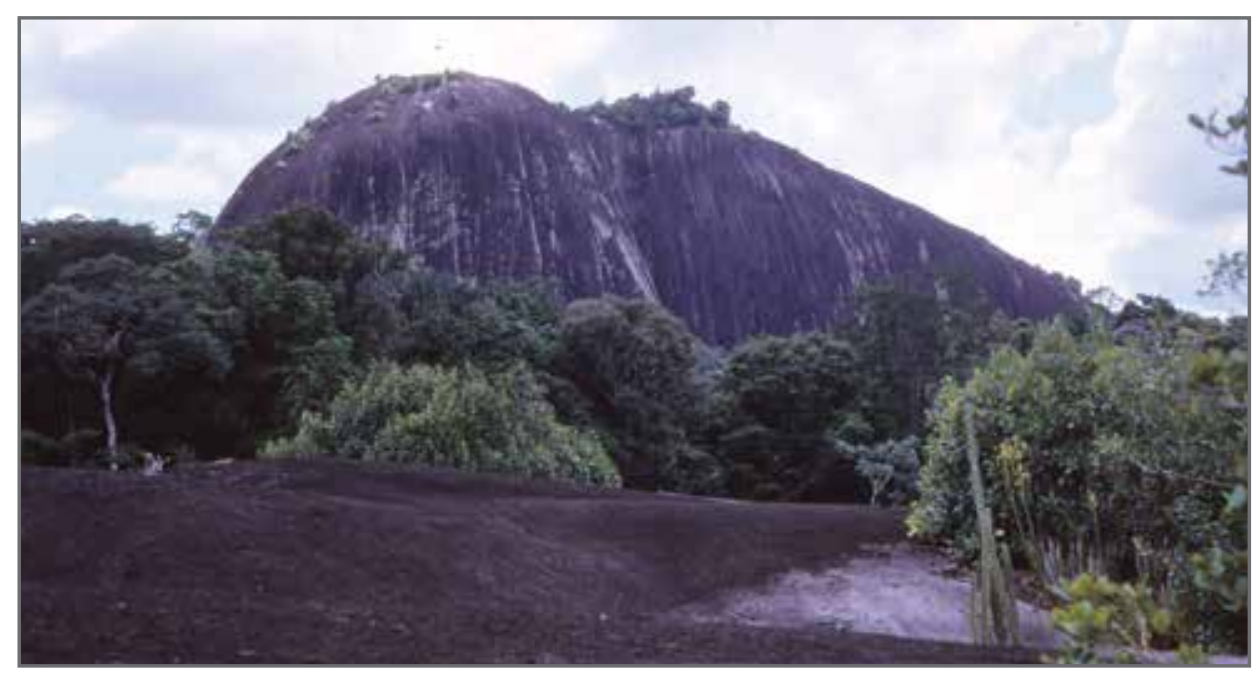

FIGURE 8. Voltzberg in Suriname.

Falls, a magnificent Harpy Eagle watched us. At night we slept in hammocks beneath the roof of an open building. I woke up frequently as Arie had told me to watch for vampire bats, which might suck your blood through the hammock. In the morning we were greeted by the loud calls of howling monkeys that sounded like distant thunder. In rock pools near the Falls, I watched with fascination giant electric eels moving around. We explored the area of the dome-shaped Voltzberg with its interesting flora growing in cirques on smooth granite flats (Figure 8). Unfortunately I did not see the bright orange Guianan Cock-of-the-Rock, which was known to occur near the Voltzberg.

After our camping trip to the Voltzberg-Raleigh Falls Nature Reserve, Arie took me to a marsh near Paramaribo where there were supposed to be Scarlet Ibises. I had never seen one in the wild before but only birds with faded plumage in a zoo. Slugging through the marsh on a dark morning, I saw my first Scarlet Ibis. Its brilliant red plumage did not seem real; perhaps it was my imagination but the ibis seemed to light up the dark morning sky.

Back in Wageningen, I prepared and sorted my frozen samples of bird tissues, fishes, frogs and snails for pesticide analyses in Canada. I planned to visit Ottawa first to drop off the frozen samples before going home to Edmonton and let CWS staff in Ottawa know the exact time of my arrival so the samples would remain preserved and not spoil. In the meantime, an SML staff invited me for a boat ride on the Maratakka River near Wageningen, where we visited a village of native inhabitants. They were friendly, and one woman gave me a large bunch of cooking bananas. I bought a beautiful purple Phalaenopsis orchid growing from a coconut husk which I later brought back with me to Edmonton. There it adorned our living room for months during the long cold winter.

When it was time to leave, I drove my Volkswagen with the samples to Paramaribo. From there I left by airplane for Ottawa, where I dropped my samples off at midnight to dedicated CWS staff. The next morning, I arrived in Edmonton, just in time to spend Christmas at home with my wife and daughter. The investigation in Suriname taught me that toxic chemical problems can be readily solved by a small multidisciplinary team with the required expertise. The closer countries and organizations cooperate, the better for humankind and environment.
1. Vermeer K, Windsor JA (1971) Spotted Sandpipers as possible indicators of mercury contamination of rivers. Blue Jay 29:59-60.

2. Vermeer K, Reynolds LM (1970) Organochlorine residues in aquatic birds in the Canadian prairie provinces. Canadian Field-Naturalist 84:117-130.

3. Vermeer K, Risebrough RW (1972) Additional information on egg shell thickness in relation to DDE concentrations in Great Blue Heron eggs. Canadian FieldNaturalist 86:384-385.

4. Hickey JJ, Anderson DW (1968)

Chlorinated hydrocarbons and egg shell changes in raptorial and fish-eating birds. Science 162:271-273.

5. Fyfe RW, Campbell J, Hayson B, Hodson K (1969) Regional population declines and organochlorine insecticides in Canadian Prairie Falcons. Canadian Field-Naturalist 83:191-200.

6. Heath RG, Spann JW, Freitzer JF (1969) Marked DDE impairment of Mallard reproduction in controlled studies. Nature 224:47-48.

7. Vermeer K (1971) A survey of mercury residues in aquatic bird eggs in the Canadian prairie provinces. Transactions of the North American Wildlife and Natural Resources Conference 36:138-152.

8. Vermeer K, Armstrong FAJ (1972) Correlation between mercury in wing and breast muscles in ducks. Journal of Wildlife Management 36:1270-1273.

9. Vermeer K, Armstrong FAJ, Hatch DRM (1973) Mercury in aquatic birds at Clay Lake, Western Ontario. Journal of Wildlife Management 37:58-61.

10. Vermeer K (1972) The crayfish Orconectis virilis as an indicator of mercury contamination. Canadian Field-Naturalist 86:123-125.

11. Vermeer $K$, Risebrough RW, Spaans $A L$, Reynolds LM (1974) Pesticide effects on fishes and birds in rice fields of Surinam, South America. Environmental Pollution 7:217-236.

12. Godfrey WE (1966) The birds of Canada. Queen's Printer and Controller of Stationary. Ottawa, Canada.

13. Spaans AL (2003) Coastal birds of Suriname. Foundation for Nature Conservation in Suriname. Paramaribo, Suriname. 